\title{
Art and being in neutrosophic communication
}

\author{
Elena Rodica Opran ${ }^{1}$, Dan Valeriu Voinea ${ }^{1}$, Mirela Teodorescu ${ }^{2, *}$ \\ ${ }^{1}$ University of Craiova, 13 A. I. Cuza Street, 200585, Craiova, Romania \\ ${ }^{2}$ Independent researcher, Craiova, Romania \\ *E-mail address: bosunpetre@yahoo.com
}

\begin{abstract}
What seems to suggest various avant-garde and artistic experimentalism movements from futurism to cubism, from expressionism to surrealism, from Picasso to the great masters of informal art is a Beauty of challenge. The avant-garde art does not arise the issue of Beauty. It is understood without saying that the new images are "beautiful" in terms of art and that should produce the same pleasure that feel the contemporaries of Rafael and Giotto in front of their works" asserts Umberto Eco (Eco, 2005). The phenomenon is due to the fact that the challenge of avant-garde tear down all aesthetic canons, observed at the moment. Art no longer aims to offer images of natural beauty, no longer occasion for calm pleasure of contemplation the harmonious forms. Instead, it wants to lead to an interpretation of the world from a different optic, wants to return to archaic or exotic models: the universe of dreams or ill mentally fantasies, visions experienced under the drugs influence, rediscovering matter, chaotic household objects current location in contexts unlikely (new object, Dadaist movement etc.), unconscious impulses, of uncertainties, of confusion, of neutrality. The study aims to explore Beauty and ugly in terms of neutrosophic concept.
\end{abstract}

Keywords: beauty in art; ugly in art; uncertainty; neutrosophic communication

\section{INTRODUCTION}

In a history of Ugliness must find its place what is called ugly of the situation. Let us imagine that we are in a familiar room, with a beautiful lamp on the table; suddenly, lamp rises into the air. The lamp, table, room are all the same, none of them became ugly, but the situation itself has become unsettling and, not being able to explain it, it seems to be an uncertainty, or frightening, depending on the degree of self-control, terrorize .

This is the principle that governs any event with ghost or other supernatural events, that scare us or something that terrifies us anything that not behave according to the natural order (Borowski, 2013; Borowski, 2014).

Researcher from the future will make but another curious inevitable discovery. Those who visit the exhibitions of avant-garde art, those who buy a sculpture "incomprehensible" or attend a happening dress and comb according to the canons of fashion, wear jeans and designer clothing, makeup according to the model of Beauty promoted by the expensive magazines, cinema, television, in other words the media. They follow therefore Beauty ideals proposed by the world of 
commercial consumption, in other words exactly against which avant-garde art struggled for more than 50 years.

How to interpret this contradiction? It is the contradiction typical twentieth century neutrosophic interpretation. At this point, the researcher will ask future times which was Beauty model proposed by the media and will discover that this century is crossed by a double break. The first one separates a model from another, all equally valid over the same decade.

\section{THE CONCEPT OF NEUTROSOPHY}

In '90, professor Smarandache from New Mexico University substantiated a theory that states the uncertainties, neutrals, fuzzy states, called Neutrosophy.

The Fundamental Thesis: Any idea $<\mathrm{A}>$ is $\mathrm{T} \%$ true, $\mathrm{I} \%$ indeterminate, and $\mathrm{F} \%$ false, where $\mathrm{T}, \mathrm{I}, \mathrm{F}$ are standard or non-standard subsets included in ${ }_{-}-0,1+_{-}$.

The Fundamental Theory: Every idea $<\mathrm{A}>$ tends to be neutralized, diminished,

balanced by $<$ Non-A $>$ ideas (not only $<$ Anti-A $>$, as Hegel asserted) - as a state of equilibrium. Neutrosophy is the base of neutrosophic logic, a multiple value logic that generalizes the fuzzy logic, of neutrosophic set that generalizes the fuzzy set, and of neutrosphic probability and neutrosophic statistics, which generalize the classical and imprecise probability and statistics respectively (Smarandache, 2005).

$<$ Neo-A $>$ has a larger sphere (including, besides parts of old $<\mathrm{A}>$, parts of $<$ Neut-A $>$ resulted from previous combinations), more characteristics, is more heterogeneous (after combinations with various $<$ Non-A $>$ ideas). But, $<$ Neo-A $>$, as a whole in itself, has the tendency to homogenize its content, and then to de-homogenize by mixture with other ideas. And so on, until the previous $<\mathrm{A}>$ gets to a point where it paradoxically incorporates the entire $\langle$ Non- $\mathrm{A}\rangle$, being indistinct of the whole. And this is the point where the idea dies, cannot be distinguished from others. The Whole breaks down, because the motion is characteristic to it, in a plurality of new ideas (some of them containing grains of the original $<\mathrm{A}>$ ), which begin their life in a similar way. As a multi-national empire. It is not possible to pass from an idea to its opposite without crossing over a spectrum of idea's versions, deviations, or neutral ideas in between (Smarandache, 2005).

"Thus, in time, $<\mathrm{A}>$ gets to mix with $<$ Neut-A $>$ and $<$ Anti-A $>$. We wouldn't say that "extremes attract each other", but $<\mathrm{A}>$ and $<$ Non-A $>$ (i.e., inner, outer, and neutron of an idea) (Smarandache, 2005).

The space of the future is described by the space-time where the observable time flows in the opposite direction (negative) - from the future to the past. Spaces with opposite flow of time are called "mirror spaces". The present space is a momentary state. The present is an intermediate state between the states of the past and the future. The statement of this problem is linked immediately with the neutrosophic system of Florentin Smarandache: where the spaces of the past and of the future as positive and negative manifolds, and the present space - as a neutral manifold, following the neutrosophy of Smarandache (Smarandache, Rabounski, 2009)

Then what is a Smarandache multi-space? Let us begin from a famous proverb. In this proverb, six blind men were asked to determine what an elephant looked like by feeling different parts of the elephant's body. The man touched the elephant's leg, tail, trunk, ear, belly or tusk claims 
it's like a pillar, a rope, a tree branch, a hand fan, a wall or a solid pipe, respectively. They entered into an endless argument. Each of them insisted that his view is right. All of you are right! A wise man explains to them: Why are you telling it differently is because each one of you touched the different part of the elephant. So, actually the elephant has all those features what you all said. Certainly, Smarandache's multi-spaces are related with the natural space. For this space, a view of the sky by eyes of a man stand on the earth can give information. The bioelectric structure of human's eyes decides that he or she cannot see too far, or too tiny thing without the help of precision instruments (Mao, 2013).

The multiverse (or meta-universe) is defined as the hypothetical set of infinite or finite possible universes (including the historical universe we consistently experience). The universe comprise everything that exists: the entirety of space, time, matter, and energy as well as the physical laws and constants/features that describe them. The various universes within the multiverse are also called parallel universes (Vlădutescu, 2013; Vlăduțescu, 2014).

\section{BEAUTY AND UGLY FROM ABSTRACT FORMS TO THE CORE OF MATTER}

\subsection{Consumer Beauty}

In 1919, Freud wrote an essay about upsetting (unheimlich). This notion already circulated for a long time in German culture and Freud had found in a dictionary a definition of Shelling that upsetting is something then what should remain hidden, but that came to light. In 1906, Ernst Jentsch wrote a Psychology of upsetting, defining it as something unusual, which causes "intellectual uncertainty" and in front of which can not "find yourself". Following Jentsch, Freud admitted that upsetting was certainly presented as the antithesis of all that is comfortable and quiet, but notice that not everything that is unusual is also unsetting; reminding Schelling, observes that upsetting seems recollection of remorse, that something forgotten thst comes out at the surface, of an unusual that appears after the disappearance of something that was known; this something troubled either the childhood each of us, or childhood of humanity - as well the reappearance of primitive fantasies about ghosts and other supernatural phenomena.

\subsection{Avant-garde and the triumph of Ugly}

Carl Gustav Jung asserts in the essay of Ullyses by Joyce (1932) that Ugly of today is the precursor sign of the great future changes. This means that tomorrow will be appreciated as a great art might seem bad today, because the taste is late against novelty. This idea is applicable to any age, but it seems mostly characterize the works produced in so-called "historic" avant-garde the first decades of the twentieth century. Artists tried their powers to "amaze the bourgeois", but the general public - and not only the bourgeois - was not only amazed, but was even outraged.

If it is maintained the difference proposed for self Ugly, formal Ugly and artistic Ugly, the artists sometimes represented self Ugly and formal Ugly, sometimes distorted simply own images, and the public saw their work as an example of artistic Ugly. Umberto Eco in History of Ugly defined "three distinct forms: self Ugly, Ugly as form and artistic representation of both". The public does not consider them beautiful representations of things ugly, but ugly representations of reality. In other words, the bourgeois was scandalized in front of a female face of Picasso not 
because he believed true copy of an ugly women - nor Picasso wanted that thing, but because they consider it a bad representation of a woman. "Hitler, a mediocre painter, condemned contemporary art considering it a "degenerate"; decades later, Nikita Khrushchev, used with Soviet realism works, being in front of the avant-garde paintings, said that they seemed painted donkey tail" reveals Umberto Eco in History of Ugly.

\subsection{Art for art's sake}

The phrase 'art for art's sake' strenghens the notion that art has its own value and should be judged apart from any subject which it might touch on, such as morality, religion, history, or politics. It teaches that judgements of aesthetic value should not be confused with those proper to other spheres of life. The idea has ancient roots, but the phrase first emerged in 19th century in France. The phrase was deployed by the writer Theophile Gautier and subsequently attracted the support of figures such as Gustave Flaubert, Stéphane Mallarmé and Charles Baudelaire. When the phrase reached Britain it became popular in the Aesthetic Movement, which surrounded painters such as James McNeill Whistler and Lord Leighton, also writers such as Walter Pater and Oscar Wilde. The phrase has been little used in $19^{\text {th }}$ century, but once its legacy has been at the heart of 20th century ideas about the autonomy of art, different bodies of thought as those of formalism, modernism, and the avant-garde. Today, it is deployed more loosely and casually, it is sometimes put to very different ends, opinions are different from defending the right of free expression, or appealing for art to uphold tradition and avoid causing offense.

\subsection{Opponents of Art for Art's Sake}

The idea that art should not be judged by criteria such as religion or politics, it has inevitably attracted opponents who either wished it to support a particular cause of reality, or refrain from expressing particular views of nature. In the $20^{\text {th }}$ Century, the concept of "art for art's sake" attracted more consistent opposition from a series of avant-gardes who reacted against the perceived isolating of abstract art, and looked for another issues, instead to reconnect art and life. Opposition in movements can be: the Constructivism, Dada and Surrealism, and other post-war movements that have revived and adopted avant-garde strategies, such as Conceptual art and Pop art. Many artists, such as Marcel Duchamp, attacked the doctrine as a falsehood, of art for art's sake arguing that it merely serves to conceal and protect a particular set of values. For Duchamp, the meaning of "art for art's sake" was merely a call to maintain a status quo: it maintained an art that had turned inward, and especially away from everyday concerns, maintaining the traditional structure of the art world - the world of galleries and museums - that supported it in fact. The Duchamp's conception and attack on "art for art's sake" was the most influential one of the past century, and very few now believe that art does exist in a separate sphere from life's other concerns. Considering that and that art is entangled in all kinds of partisan issues, most of artists now believe that making aesthetic value judgments - declaring one work of art to be better than another - is almost impossible. 


\section{NEUTROSOPHY BETWEEN TRUTH AND FALSE}

The concept that art is "not of this world" detaches art from life and locates art in an aesthetic realm that transcends human existence. It implies that "beyond the world of materiality there is a universal and eternal state of Truth that underlies all human values" as asserts A. Kurtis. Followers of the existence of this "other" world seem to believe that some humans have access to this state-but that not everyone can dip into this realm. Knowledge about the Truth, about art is available only, in their conception, to those few who have a certain "delicacy of imagination" or a "standard of taste" and this thing allow them to discern good art from bad, or real art from counterfeit art. There are philosophers who fall into this category, Hume states that men of delicate taste are rare but can be distinguished from the rest of mankind "by the soundness of their understanding and the superiority of their faculties" (Hume, 1975). Clive Bell also, claims that significant form in great art provokes a subjective aesthetic emotion in anyone capable of feeling it. Bell goes on to say that not "everyone has this capability because most people miss the full significance of art, or appreciate visual art impurely" (Bell, 1913).

The political purpose to which high art is promoted may vary from culture to culture. Unlike Western cultures where art is used to confirm the established social system, China used art to overthrow the social system. Chairman Mao declared that "there is in fact no such thing as art for art's sake, art that stands above classes, art that is detached from or independent of politics" (Kurtis, 2014). Mao believed that art can be a powerful revolutionary weapon that prepares the masses ideologically so that the people can fight the enemy with the heart and mind. However, because Mao proclaimed that art must have "artistic power" as well as revolutionary content to be effective, so he disclosed that he evaluated art not fulfilled its political purpose effectively. Harold Rosenberg, on the other hand, asserts that "art in this century has proven to be almost totally ineffective as a political weapon, although totalitarians cannot tolerate the presence of any rival intellectual eliteincluding aesthetic radicals" (Rosenberg, 1959). He also suggests that governments themselves to become the artists by crises-crossing fact and illusion (Rosenberg, 1959). It is obvious that the artist cannot just create art for art's sake and be detached from life, because the aesthetic realm does not stimulate the creation of art, declares also Rosenberg. "Creative energies require the stimulation of values-religious, philosophical, political-outside of art" shows Rosenberg (Rosenberg, 1959). To insulate the mind and art from the drama of politics and history is to leave fine art on the level of craft, claims Rosenberg.

Hegel's Romantic stage (extended forward in time and developing in ways Hegel would perhaps have found incomprehensible) corresponds to the Modern period. The philosopher and art critic Arthur Danto, in his essay 'The End of Art' (published in a collection of essays entitled The Death of Art in 1984), and further developed in his 1997 book After the End of Art: Contemporary Art and the Pale of History), applied Hegel's thesis to Modern art, arguing that indeed the traditional linear history of art since the Renaissance has come to an end, replaced by a pluralism in which everything can or has the potential to be art (Witcomb,1995).

But it seems very likely that from the prevailing pluralism will emerge a new art. Applying the dialectical method of thesis-antithesis-synthesis (concept also mentioned by Smarandache in Neutrosophic Logics), associated with Hegel, the process must inevitably continue. Witcomb deducts, "if Modernism is the original thesis, it contains within it the seeds of its own antithesis (which in retrospect might be identified as those rooted in Marcel Duchamp's "ready-mades" and the claims of Dada), from which has emerged the synthesis of pluralism where nothing can be denied the status of art if it is claimed to be such" (Witcomb, 1995). In this situation, within the current pluralism of trends (which is the new thesis), must lie the antithetical germ which will give 
rise to a new and presumably postmodern trend or post-Romantic synthesis. "What form this new art will take, and what role, if any, it will play in the post-modern world, remains to be seen", shows Witcomb (Witcomb, 1995).

Looking into Smarandache's theory: Hegel's and Marx's antithesis <Anti-T $>$ does not simply arise from thesis $<\mathrm{T}>$ only. $<\mathrm{T}>$ appears on a background of preexistent ideas, and mixes with them in its evolution. $<$ Anti-T $>$ is built on a similar ideational background, not on an empty field, and uses in its construction not only opposite elements to $<\mathrm{T}>$, but elements of $<$ Neut-T $>$ as well, and even elements of $<\mathrm{T}>$. For, a thesis $<\mathrm{T}>$ is replaced not only by an antithesis $<$ Anti- $\mathrm{T}>$, but also by various versions of neutralities $<$ Neut-T $>$.

Smarandache resumes this at: "neuter-thesis (ideational background before thesis), pre-thesis, thesis, pro-thesis, non-thesis (different, but not opposite), anti-thesis, post-thesis, neo-thesis. Hegel's scheme was purist, theoretic, idealistic. It had to be generalized: from simples to organicism" (Smarandache, 2005).

Damien Hirst was asked why For the Love of God in this manner, he just answered: "I just thought, What can you pit against death?" (Hirst, 2008). 'For the Love of God' acts as a reminder that our existence on earth is transient. In his work, Hirst combined the imagery of classic memento mori with inspiration drawn from Aztec skulls and the Mexican love of decoration and attitude towards death. Hirst also explains of death: "You don't like it, so you disguise it or you decorate it to make it look like something bearable - to such an extent that it becomes something else" (Hirst, 2008).

Analyzing from point of neutrosophic view, it can be associated:

oBeyond philosophy there is a philosophy. Beyond arts there are arts. Beyond religion there is a religion. The matter is of neutrosophic essence;

$\circ$ God is the supreme nature. The divine reality inside trivial, and reciprocally. He is the supreme neutrosopher of all times. He is the absolute, the nothingness, the nonbeing, $<\mathrm{A}>,<$ Neut$\mathrm{A}>$, and $<$ Anti-A $>$ simultaneously;

oHuman gets to identify with God, on the way of soul's liberation and of status of detachment from the world (abgeschlidenheit) [Meister Eckhart, $<$ Die DeutscheWerke $>$ ]. But human gets to identify with Devil as well, by revealing the misery of soul and private life;

oThe Ultimate Paradox: Living is the process of dying.

Stephen Hicks in his article Why Art Became Ugly, stated that "Art must be a quest for truth, however brutal, and not a quest for beauty". In this situation, the question became: "What is the truth of art? The first major claim of modernism is a content claim: a demand for a recognition of the truth that the world is not beautiful. The world is fractured, decaying, horrifying, depressing, empty, and ultimately unintelligible" (Hicks, 2004). Some past artists had believed the world to be ugly and horrible - but in their works, they had used the traditional realistic forms of perspective and color to represent this. The new improvement of modernists was to assert that form must match content (Hicks, 2004). In modernism the art should not use the same perspective and color as traditional because those forms suppose an orderly, integrated, and knowable reality, different of their conception (Hicks, 2004).

The relevant example is Edvard Munch who got there first (The Scream, 1893): "If the truth is that reality is a horrifying, disintegrating swirl, then both form and content should express the feeling", notes Hicks (Hicks, 2004). Later, Pablo Picasso got there second (Les Demoiselles 
d'Avignon, 1907): "If the truth is that reality is fractured and empty"notes also Hicks, then both "form and content must express that" (Hicks, 2004). Analyzing Salvador Dali's surrealist paintings, his works go a step further: "If the truth is that reality is unintelligible, then art can teach this lesson by using realistic forms against the idea that we can distinguish objective reality from irrational, subjective dreams", mentions Hicks (Hicks, 2004).

Tatarkiewicz is right in suggesting that if we restrict the notion of beauty, it bears little explanatory power for the variety of aesthetic experience (Lorand, 2007).

Passmore asserts that, "There is something suspect ('phony') about 'beauty'. Artists seem to get along quite well without it: it is the café-haunters, the preachers, the metaphysicians, and the calendar-makers who talk of beauty.... 'Beauty' is always nice; always soothing; it is what the bourgeoisie pay the artist for ... it is the refuge of the metaphysician finding a home for art in his harmonious universe...." (Passmore, 1954). In this context, according to Passmore, beauty is useless and unreliable not because its range is too narrow, but rather because it serves or expresses the wrong social values. On the other hand, Beauty is not always "nice" and "soothing"; it can generate pain or restlessness, as well as great pleasure. Also, one person's beauty may be another person's kitsch. In associating beauty with metaphysicians, Passmore overlooks the fact that the great metaphysicians of the seventeenth century hardly ever mention beauty, considered it central to their "harmonious universe" (Lorand, 2007). Spinoza, for one, regarded beauty as a subjective, irrational concept that merely expresses the individual standpoint (Spinoza, 1993).

In his Languages of Art, Goodman briefly comments on the irrelevance of beauty to art appreciation. "Folklore has it that a good picture is pretty. At the next higher level, pretty is replaced by 'beautiful', since the best pictures are often obviously not pretty. But again, many of them are in the most obvious sense ugly. If the beautiful excludes the ugly, beauty is no measure of aesthetic merit; but if the beautiful may be ugly, then 'beauty' becomes only an alternative and misleading word for aesthetic merit" (Lorand, 2007). Goodman offers two arguments: (1) "Beauty is a confusing, and therefore useless, concept"; and (2) "Beauty cannot be a key concept in art appreciation, because many (good) works of art are ugly" (Goodman, 1976). Ruth Lorand makes an analysis regarding Goodman statement:

1. Goodman rightly suggests that there are (at least) two ways to understand the word "beauty": (i) "beauty" as an inclusive notion that is equivalent to "aesthetic value"; (ii) "beauty" as aesthetic praise. Resulted double meaning for "Beauty "that can be interpreted as a paradox. Many words have multiple meanings. For instance, we use "art" sometimes in a classificatory sense that includes good and bad art, and sometimes as an expression of praise (Dickie, 1974). "Analytic philosophers sometimes focus on the role of words and decide the fate of a concept based on linguistic fashions" concludes Lorand (Lorand, 2007). Wittgenstein remarked that, "in real life, when aesthetic judgments are made, aesthetic adjectives such as 'beautiful', 'fine', etc. play hardly any role at all" (Wittgenstein, 1970). Wittgenstein further states, that "right", "correct" and "precise" are more likely to be used as aesthetic praises;

2. Goodman's second argument concerning the detachment of art from beauty, expresses the general consensus prevailing in the last century. Goodman dismisses the idea that good art is necessarily beautiful. He claims that, "since some good works of art are ugly, beauty cannot be an essential feature of art" (Goodman, 1976). Similarly, Danto sustains that "modern art presents clear evidence that good art need not be beautiful" (Danto, 2003). 


\section{FUTURE OF ART}

The artists, critics of art, philosophers wonder: Where could art go after death of modernism? Postmodernism did not go, and has not gone, far. It needed some content and some new forms, but it did not want to go back to classicism, romanticism, or traditional realism, it need to progress to find a new concept.

At the end of the nineteenth century, the art world reached out and drew upon the broader intellectual and cultural context of the late 1960s and 1970s. It were absorbed the trendiness of Existentialism's absurd universe, also the failure of Positivism's reductionism, and the collapse of socialism's New Left (Hicks, 2004). The art world was connected to intellectual heavy weights such as Thomas Kuhn, Michel Foucault, and Jacques Derrida, and it took its cue from their "abstract themes of antirealism, deconstruction, and their heightened adversarial stance to Western culture. From those themes, postmodernism introduced variations on modernism" notes Stephen Hicks (Hicks, 2004).

Postmodernism re-introduced the content, but only self-referential and an ironic one. Similarly to philosophical postmodernism, artistic postmodernism rejected any form of realism and became anti-realist. Art cannot be about reality or nature, because, according to postmodernism, "reality" and "nature" are merely social constructs. Also, postmodernism set itself to a more ruthless deconstruction of traditional categories that the modernists had not fully eliminated. Modernism had been "reductionist, but some artistic targets remained" (Hicks, 2004).

\section{CONCLUSION}

In the title of her 1984 book, Suzi Gablik asks 'Has Modernism Failed?' What does she mean? Has modernism 'failed' simply in the sense of coming to an end? Or does she mean that modernism failed to accomplish something else? The presupposition of the latter is that modernism had goals, which it failed to achieve. The same author, asserts: "In the complex transition from modernism into postmodernism, a new terrain of consciousness is being occupied one in which the limits of art seem to have been reached, and overturning conventions has become routine. As long as we are willing to consider anything as art, innovation no longer seems possible, or even desirable".

In this mixed ideas, Paul Valéry stated: "Beauty is a kind of death". Antonin Artaud, together with the artists Soutine and Bacon, join forces and turn 'beauty' into 'cruelty' (cruauté) and also sadomasochism. The most contemporary art certainly questions the existence, the significance and the value of the beautiful in favor of the new, the intense, the uncanny, as Deleuze suggested. Our time concentrates on all sorts of mutations, our mentality has become time-sensitive and all this disputes the beautiful since beauty is unchanging and stable. Beauty means calm, serene, harmonious and brings contemplation, pleasure. But, from Breton to Lyotard, precisely this becomes a subject of a fundamental criticism. But, "Beauty will be convulsive or not at all", writes Breton. The introduction of the unconscious welcomes us into the age of the Different (le different, Lyotard), including a revaluation of the instant and of instability, disorder and imperfection, and on the other hand, uncertainties. Valéry concludes that aesthetics is no longer a science of the beautiful but it became a science of sensations, a science of a convulsive subjectivity whose sensitivity functions chaotically and is dependent of the context. Indeed, contemporary art has demoralized the classic aesthetics of the beautiful. However, this cannot result in an a priori, global and desperate renunciation of the idea of beauty that will be the result of a posteriori. From point of Neutrosophy view it is obvious that: Everything is possible, even the impossible! 


\section{References}

[1] Arthur C. Danto (2003). The Abuse of Beauty. Chicago and La Salle: Open Court.

[2] George Dickie (1974). Art and the Aesthetic: An Institutional Analysis. Ithaca, New York: Cornell University Press.

[3] Andrzej Borowski, International Letters of Social and Humanistic Sciences 14 (2014) 33-41.

[4] W. A. Quffa, D. V. Voinea, Contemporary Readings in Law and Social Justice (2) (2013) 261266.

[5] Spinoza (1993). Etica, Bucuresti: Editura Antet.

[6] Nelson Goodman (1976). Languages of Art. Indianapolis and Cambridge: Hackett Publishing Company.

[7] Ștefan Vlăduțescu, International Letters of Social and Humanistic Sciences 15(2) (2014) 164170.

[8] Paolo Di Sia, International Letters of Social and Humanistic Sciences 3 (2015) 21-28.

[9] J. A. Passmore (1954). The Dreariness of Aesthetics. In W. Elton, ed. Aesthetics and Language. Oxford: Basil Blackwell.

[10] Florentin Smarandache (2005). A Unifying Field in Logics: Neutrosophic Logic. Neutrosophy, Neutrosophic Set, Neutrosophic Probability: Neutrsophic Logic. Neutrosophy, Neutrosophic Set, Neutrosophic Probability. Infinite Study.

[11] Ludwig Wittgenstein (1970) Lectures and Conversations on Aesthetics, Psychology \& Religious Belief. Oxford: Basil Blackwell.

[12] Umberto Eco (2005). Istoria Frumosului. Bucuresti: Editura RAO.

[13] Ştefan Vlăduţescu, American International Journal of Contemporary Research 3(10) (2013).

[14] Umberto Eco (2007). Istoria Uratului. Bucuresti: Editura RAO.

[15] Hegel, 1966, Prelegeri de estetica, vol. I, Bucuresti, Editura Academiei.

[16] Florentin Smarandache, Stefan Vladutescu, Revista de Cercetare şi Intervenţie Socială, (46) (2014) 243-254.

[17] Ștefan Cojocaru (2005). Metode apreciative în asistența socială: ancheta, supervizarea, studiul de caz. Polirom.

[18] Antonio Sandu (2014). Elemente de sociologie. București: Editura Tritonic.

[19] Oprea-Valentin Buşu, Mirela Teodorescu, Daniela Gîfu, International Letters of Social and Humanistic Sciences 27 (2014) 82-93.

[20] Răzvan Alexandru Călin (2014). Psychology of the Archetype Symbol in Orthodox Church Picture and Architecture. Neutrosophy, Paradoxism and Communication, 178. 
[21] Arthur C. Danto (1997). After the End of Art: Contemporary Art and the Pale of History. Princeton: Princeton University Press.

[22] G. W. F. Hegel (1975). Aesthetics: Lectures on Fine Art. Oxford: Clarendon Press.

[23] F. Smarandache (1998). A Unifying Field in Logics, Neutrosophic Logic/Neutrosophy, Neutrosophic Set, Neutrosophic Probability, Am. Res. Press.

[24] F. Smarandache (2000). Linguistic Paradoxes and Tautologies. Collected Papers, Vol. III, 3, 122.

[25] Andrzej Borowski, International Letters of Social and Humanistic Sciences 14 (2014) 7-17.

[26] Ștefan Vlăduțescu, Xenia Negrea, Dan Valeriu Voinea (2014). Interpersonal Communicational Manipulations. Postmodern Openings.

[27] D. Cojocaru, A. Sandu, S. Cojocaru, Journal for the Study of Religions and Ideologies (28) (2011) 65-83.

[28] Maria Nowicka-Skowron, Sorin Mihai Radu (2014). Innovation process modelling. Current Communication Difficulties, 104.

[29] Max G. Craig, Journal of Studies in Social Sciences 8(1) (2014).

[30] Ştefan Vlăduţescu (2014). Actants of manipulative communication. International.

[31] Smarandache, F. (2002). 2002b), Neutrosophy, A New Branch of Philosophy, in MultipleValued Logic. In An international journal.

[32] A. Borowski, International Letters of Social and Humanistic Sciences (27) (2014) 100-110.

[33] Smarandache, F. (2010). Neutrosophic Logic as a Theory of Everything in Logistics. Multispace and Multistructure. Neutrosophic Transdisciplinariry (100 Collected Papers of Sciences), 525-527.

[34] Mihaela Mocanu, International Letters of Social and Humanistic Sciences 4 (2015) 46-55.

[35] Florentin Smarandache \& Ștefan Vlăduțescu (2014). Communicative Universal Convertibility Matter- Energy-Information. Social Sciences and Education Research Review.

[36] Smarandache, F. (2010). Neutrosophic Logic-A Generalization of the Intuitionistic Fuzzy Logic. Multispace \& Multistructure. Neutrosophic Transdisciplinarity (100 Collected Papers of Science), 4, 396.

[37] F. Smarandache, Ș. Vlăduţescu (2014). Neutrosophic Emergences and Incidences in Communication and Information. Saarbrucken: LAP Lambert Academic Publishing.

[38] L. Mao (2003). Proceedings of the First International Conference On Smarandache Multispace \& Multistructures (28-30 June 2003, Beijing, China), Edited by Linfan Mao.

[39] D. Hume (1975). A Treatise of Human Nature. edited by L. A. Selby-Bigge, 2nd ed. revised by P. H. Nidditch, Oxford: Clarendon Press, 
[40] Ștefan Vlăduțescu, Dan Valeriu Voinea \& Elena Rodica Opran (2014). Theory and practical of the paradoxist aesthetics. In Neutrosophy, Paradoxism and Communiction. Craiova: Sitech.

[41] Aili Kurtis, Essay - Art for art's sake - http://www.ailikurtis.com/ArtForArtsSake.html

[42] Ștefan Vlăduțescu, Claudiu Marian Bunăiașu, Alexandru Constantin Strungă, International Letters of Social and Humanistic Sciences 3 (2015) 53-60.

[43] Harold Rosenberg (1959). The Tradition of the New. Ayer Co Pub.

[44] Christofer Witcomb (1995). Art History Resources- The End of Art. London

[45] I. C. Dima, J. Grabara, S. Vlăduțescu (2014). Comparative study on online education in Romania and Poland in terms of current globalization. Polish Journal of Management Studies.

[46] Stephen Hicks (2004). Why Art Became Ugly, issue of Navigator magazine, The Atlas Society precursor to The New Individualist.

[47] Ruth Lorand (2007). In Defense of Beauty, www.aestetics-online.org

[48] D. Gifu, V., Modrak, M. Teodorescu, International Letters of Social and Humanistic Sciences (24) (2014) 56-65.

[49] Ștefan Vlăduțescu, International Letters of Social and Humanistic Sciences 15(2) (2014) 164170.

[50] Dan Ionescu, Mirela Teodorescu, International Letters of Social and Humanistic Sciences 27 (2014) 94-99.

[51] Mihaela Gabriela Păun, Mirela Teodorescu (2014). Hermeneutics can make beauty and ugly as neutral (as neutrosophic). Social Sciences and Education Research Review.

[52] Janusz Grabara, Michal Kolcun, Sebastian Kot, International Journal of Education and Research 2(2) (2014).

[53] Ştefan Vlăduțescu, European Scientific Journal 9(32) (2013).

[54] A. Sandu (2009). Tehnici afirmativ-apreciative. O sociopedagogie a succesului. Lumen.

[55] A. Sandu, Postmodern Openings (3) (2014) 49-66.

[56] B. Ślusarczyk, R. Golnik, R. The recruitment process in transnational corporations. Polish Journal of Management Studies.

[57] Ștefan Vlăduțescu \& Florentin Smarandache (2014). Five Computational Actions in Information Processing. Social Sciences and Education Research Review.

[58] M. G. Mangra, E. A. Cotoc, A. Traistaru, Journal of Studies in Social Sciences 6(1) (2013).

[59] J. H. Gasderell, International Letters of Social and Humanistic Science 22 (2014) 85-91.

[60] C. M. Bunăiașu, Ș. Vlăduțescu, A. C. Strungă, Revista Romaneasca pentru Educatie Multidimensionala 6(2) (2014) 17-27. 
[61] Adrian Nicolescu, Mirela Teodorescu, International Letters of Social and Humanistic Sciences 2(1) (2015) 48-59.

[62] D. Gifu, J. Novak-Marcincin, M. Teodorescu, International Letters of Social and Humanistic Sciences (27) (2014) 22-33.

[63] Jozef Novak-Marcincin, Adrian Nicolescu, Mirela Teodorescu, International Letters of Social and Humanistic Sciences 1(2) (2015) 140-145.

[64] Paolo Di Sia, International Letters of Social and Humanistic Sciences 1(2) (2015) 146-153.

[65] Jacek Tittenbrun, International Letters of Social and Humanistic Sciences 3 (2015) 29-44. 